\title{
Dentofacial injuries in commercial motorcycle accidents in Cameroon: pattern and cost implication of care
}

\author{
Ashu Michael Agbor ${ }^{1}$, Clement Chinedu Azodo 2 , Etta Barnabas Ebot ${ }^{1}$, Sudeshni Naidoo $^{3}$
}

\author{
1. Department of Dentistry Faculte des sciences de la Sante, Université des Montagnes BP 208, Bangangté \\ Cameroon \\ 2. Faculty of Dentistry, University of Benin Benin City Nigeria \\ 3. Department of Community Dentistry, University of the Western Cape, Cape Town South Africa
}

\begin{abstract}
Objective: To assess the pattern of dentofacial injuries in commercial motorcycle accidents among riders and passengers in Cameroon.

Methods: This was a hospital based study conducted in 6 out of 10 regional capitals in the months of December 2011 to September 2012. Analyzed information included age, gender, residence, role on the motorcycle (rider or passenger), type, pattern and month of injury, cost, duration and patient's perception about the cost of treatment.

Results: A total of 387 patients were studied with majority of the patients being $21-30$ years (39.8\%), males (63.8\%), passengers $(57.3 \%)$ and urban dwellers (85.8\%). Most of the injuries occurred in December (20.7\%), January (19.4\%) and February $(20.2 \%)$. Soft tissue injuries were most frequent $(91.2 \%)$ followed by trauma to the teeth $(83.5 \%)$, of which $62.3 \%$ were tooth loss. Mandibular fracture was commoner than maxillary fracture; (45\% versus $25.3 \%$ ). A total of $44.2 \%$ of patients received their treatment as in-patients. The treatment of the dentofacial injuries among $64.3 \%$ of the patients lasted for more than a month. A total of $51.9 \%$ of the patients spent 100,000 francs (\$200) or more for their treatment. More than half $(51.4 \%)$ of the patients perceived the cost of treatment as expensive.

Conclusion: Dentofacial injuries in commercial motorcycle accidents necessitated hospital admission and lengthy treatment time with high attendant cost. Preventing these injuries will serves as a form of poverty reduction as money that will be used by the victim to better their life is not used to correct deformities or treat injuries.
\end{abstract}

Keywords: Dentofacial injuries, commercial motorcycle accidents, Cameroon

African Health Sciences 2014;14(1): 77-82 http://dx.doi.org/10.4314/ahs.v14i1.12

\section{Introduction}

The increased commercial motorcycle accidents pose a serious public health problem as these constitute a large portion of road traffic accidents in developing countries. ${ }^{1-6}$ The unavailability of organized urban public transport coupled with strict rules and crackdown on non-road worthy vehicles in Cameroonsince 2010, created a deficiency in urban transport. Hence commercial motorcycle popularly known as bendsikin and okada/ach$a b a$ in French and English speaking Cameroon respectively has become a com mon means of transportation in major cities in the country. The low cost of purchase, fuel consumption and easy maintenance has continued to favour an increase in motorcycle transportation. Other postulations for

\section{Corresponding author: \\ Agbor Michael Ashu Emmanuel \\ Faculty of dentistry \\ Universite des Montagnes \\ B P. 208 bagante- Cameroon \\ Email:agborasm@yahoo.com}

increased utilization of motorcycle transportation is rooted on the fast nature of motorcycles which reduces time wasted in traffic congestion within the poor road networks, unplanned urban transportation with the added advantage of closer access to areas of residence and business. The increased use of motorcycle is accompanied with increased road traffic accidents. This is related to the poor regulation and disorganized nature of this means of transportation and whose operators lack formal road traffic instruction.

Dentofacial injuries that commonly occur in motorcycle accidents pose significant psychological, functional and aesthetic problems to both riders and passengers. ${ }^{7}$ Studies on dentofacial injuries in motorcycle accidents show that injuries occur as single vehicle collision with an object, another vehicle or falls. ${ }^{8,9}$ Seasonal variation in maxillofacial injuries resulting from road accidents has been reported in hospital based studies. ${ }^{10,11}$ These have been attributed to the increased opportunities for outdoor activities and increased travel due to good weather during the months of November to February making up the dry season.In contrast there is decreased travel with greater pre 
caution due to visibility and terrain problems during rainy season. The assessment of dentofacial injuries in commercial motorcycle accidents in Cameroon is expected to generate baseline information that may interest policy formulation and also assist in the development of preventive programmes.

The objective of the study was to assess the pattern of dentofacial injuries in commercial motorcycle accidents among riders and passengers in Cameroon.

\section{Methods and Materials}

This was a hospital based study conducted in 6 out of 10 regional capitals of Cameroon in the months of December 2011 to September 2012. Douala, Yaounde, Garoua, Ngaoundere, Bamenda and Buea are the capital of Littoral, Centre, North, Adamawa, Northwest and Southwest, respectively. These areas capitals have large numbers of commercial motorcycles estimated above 3000 with a high population using this means of transportation. ${ }^{12}$

This study was of 387 cases of dentofacial injuries attained from commercial motorcycle accidents who sought treatment at hospitals and dental clinics. Information collected from the participants included age, gender, area of residence and perception about the cost of treatment. Other data with reference to type of injury, month and duration of injury were obtained from case notes of patients available at the units. The patient information was kept confidential. Only cases of dentofacial injuries from commercial motorcycle riders and their passengers were studied, injuries of this nature from other sources were excluded. Data collected was analyzed using a computer software program EpiInfo 3.1.2. Ethical clearance for this study was obtained from the Ministry of Higher Education and Scientific
Research of Cameroon.

\section{Results}

The distribution of dentofacial motorcycle accident injuries in the six regions were as follows in descending order: Centre-129 (33.3\%), Littoral-102 (26.4\%), Northwest-61 (15.8\%), North 34 (8.8\%), Southwest-31 $(8.0 \%)$ and Adamawa-30 (7.8\%). In this study, majority of the patients were young adults [156 (40.3\%) aged 2130 years and $104(26.9 \%)$ aged $31-40$ years]. Of the 387 cases studied, $244(63.0 \%)$ and $138(37.0 \%)$ were males and females respectively giving a male to female ratio of 1.8:1. A total of $167(43.2 \%)$ of the patients were motorcycle riders and $216(56.8 \%)$ were passengers. Urban dwellers constituted $332(85.8 \%)$ of the patient while $55(14.2 \%)$ of the patients were rural dwellers (Table 1). The injuries over the 7 months duration were as follows: September-51 (13.2\%), October-57 (14.7\%), November-45 (11.6\%), December-80 (20.7\%), January-75 (19.4\%), February-78 (20.2\%) and March 1 (0.3\%)

A total of $171(44.2 \%)$ of patients received their treatment as in-patient while $216(55.8 \%)$ were treated on the outpatient basis. Soft tissue injuries were very frequent-353 (91.2\%), trauma to the teeth constituted 323 $(83.5 \%)$ of cases with $241(62.3 \%)$ being tooth loss. Mandibular fracture was commoner than maxillary fracture; [(175 (45\%) versus $98(25.3 \%)]$. The treatment of the dentofacial injuries among $249(64.3 \%)$ of the patients lasted for more than a month and more than half- $201(51.9 \%)$ of the patients spent 100,000 francs $(\$ 200)$ and above for the treatment; $>120,000$ francs (\$240)-34 (8.8\%), 120,000 francs (\$240) -55 (14.2\%) and 100,000 francs (\$200)-112 (28.9\%). A total of 199 $(51.4 \%)$ of the patients perceived the cost of treatment for the dentofacial injuries among as being expensive (Table 2). 
Table 1: Demographic characteristics of cases studied at the regional capitals of Cameroon

\begin{tabular}{|c|c|c|}
\hline 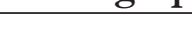 & Gen & \\
\hline & $\begin{array}{c}\text { Female } \\
\mathrm{n}(\%)\end{array}$ & $\begin{array}{l}\text { Male } \\
\mathrm{n}(\%)\end{array}$ \\
\hline $\begin{array}{l}\text { Variable } \\
\text { Age (years }\end{array}$ & & \\
\hline $0-10$ & 18 (12.6) & $17(7.0)$ \\
\hline $11-20$ & 27 (18.9) & $36(14.8)$ \\
\hline $21-30$ & $54(37.8)$ & $102(41.8)$ \\
\hline $31-40$ & 38 (26.6) & $66(27.0)$ \\
\hline $41-50$ & $5(3.5)$ & $16(6.6)$ \\
\hline $51-60$ & $1(0.7)$ & $5(2.0)$ \\
\hline$>60$ & $0(0.0)$ & $2(0.8)$ \\
\hline Status & & \\
\hline Rider & $6(4.2)$ & $161(66.0)$ \\
\hline Passenger & 137 (95.8) & $83(34.0)$ \\
\hline Location & & \\
\hline Urban & $123(86.0)$ & $209(85.7)$ \\
\hline Rural & $20(14.0)$ & $35(14.3)$ \\
\hline Total & $143(100.0)$ & $244(100.0)$ \\
\hline
\end{tabular}


Table 2: Pattern and cost implication of care for dentofacial injuries among the participants

Variable

Hospital admission

Yes

No

\section{Type of injury}

Soft tissue

Tooth loss

Other injuries to teeth

Mandibular fracture

Maxillary fracture

Palatal fracture

Duration of treatment

More than 1 month

3-4 weeks

1-2 weeks

4-7 days

1-3 days

Cost of treatment

Greater than 120000

120000

100000

80000

60000

40000

Patient perception of the cost of treatment

Very expensive

Expensive

Moderate

Cheap
Rider

n $(\%)$

78 (46.7)

89 (53.3)

152 (91.0)

97 (58.1)

29 (17.4)

80 (47.9)

46 (27.5)

4 (2.4)

108 (64.7)

23 (13.8)

33 (19.8)

$0(0.0)$

3 (1.8)

19 (11.4)

22 (13.2)

48 (28.7)

25 (15.0)

27 (16.2)

26 (15.6)
Passenger

n $(\%)$

93 (42.3)

127 (57.7)

201 (91.4)

144 (65.5)

53 (24.1)

94 (42.7)

52 (23.6)

6 (2.7)

141 (64.1)

$22(10.0)$

39 (17.7)

15 (6.8)

$3(1.4)$

$15(6.8)$

$33(15.0)$

$64(29.1)$

$28(12.7)$

32 (14.5)

$48(21.8)$

25 (11.4)

$112(50.9)$

54 (24.5)

$29(7.5)$

\section{Discussion}

The majority of dentofacial injury cases found in this study were young adults in the age range of 21 to 40 years. This is similar to findings of studies reported from Kuala Lumpur, Malaysia ${ }^{8}$ and Taipei, Taiwan. ${ }^{13}$ The active nature of group which involves movement from place to place as part of job seeking, going to work or delivering services encourage their use of commercial motorcycle, a fast and cost-effective mode of transportation in developing countries. ${ }^{11}$ In this study, more males than females were affected. The higher male than female dentofacial injuries experience has been reported in several other studies., ${ }^{4,8,9,11,14}$ Perhaps, as breadwinners for many families tend to be men, their mobility is therefore more and thereby exposed to the associated risks. This may support the observed gender trend. Furthermore, motorcycle riders were predominantly males also contributing to the larger number of males than females found with injuries.

The larger proportion of victims were from urban settings. This shows that injuries of this nature occur mainly in urban settings where there are intense economic activities with a busy road network motivating the urban dwellers to use commercial motorcycle transport. Alicioğlu et al. ${ }^{7}$ noted that increase in motorcycle accidents occur in parallel with the increasing number of motorcyclists. A significant increase in motorcyclerelated maxillofacial injuries has been observed in most urban and suburban centres of the neighbouring country, Nigeria. ${ }^{15}$ The frequent traffic jams due to a poor road network in most urban and suburban centres of 
developing countries made motorcycles, a popular mode of transportation with the ability to pass through narrow ways. The increased use of motorcycle is accompanied with increased road traffic accidents which are related to the poor regulation and disorganized nature of this means of transportation and whose operators lack formal road traffic instruction. This was moreso confirmed as more developed regions, Centre-128 (36.3\%) and Littoral-101 (28.6\%) regions were the leading regions with the studied dentofacial injuries.

In contrast to Oginni et al. (2006) ${ }^{9}$ study among Nigerian intracity road users, it was found that passengers were more commonly victims of the motorcycle accidents. This can be explained by the fact that motorcycle passengers have slightly higher chances of sustaining dentofacial injuries from commercial motorcycle accident due their lesser visibility of anterior view than the riders with eventual reduction of effective dentofacial injury accident preventive movement.

In terms of the general pattern of injuries seen in previous related studies $8,11,16,17$, the mandible was more affected than the maxilla in this study. Identification of mandible as the most common facial bone involved in fracture due to it's prominence has been documented. It is notable a large number of soft tissue injuries occurred in this study which is in consonance with the findings of previous studies in Nigeria, Brazil and Malayasia. ${ }^{8,18,19}$ Motorcycle accidents are associated with abrasions, laceration of skin, lip, buccal and lingual mucosa, and soft tissue avulsion with different mechanism of injuries like falls, burns, unexpected teeth closure on tongue or lip, collision between rider and passenger, collision with parts of the motorcycle and stationary objects. Avulsion has been reported as the most common dentoalveolar injury in motorcycle accidents ${ }^{18}$ meaning that commercial motorcycle ac cidents do contribute to tooth loss in Cameroon.

In evaluating the severity of the injuries with respect to hospital admission and treatment duration, it was founded that $44.2 \%$ had hospital admission and more than half of them completed the treatment for their dentofacial injuries after one month. This implies that dentofacial injuries from commercial motorcycle accidents are severe, needing interventions of dental surgeons to correct and restore the injured dentofacial areas. Hospitalization for up to 150 days for care of motorcycle accident related injuries has been reported. ${ }^{7}$

The high rate of hospital admission and long duration of treatment found in this study reveals that dentofa- cial injuries from motorcycle accidents impose a heavy financial burden on the victims and their families. It thereby means that preventing these injuries will serve as a form of poverty reduction as the money that will be used by the victim to better their life is not used to correct deformities or treat injuries.

The months of December through to February registered the highest number of dentofacial injury cases. This could be due to fact that these are periods of festivities and intensive economic activity in this study area with multiple public and religious holidays increasing movement and accidents. The heightening of the prevalence of alcohol use while riding during this period is a contributory explanation20 for the seasonal variation in the prevalence of commercial motorcycle-related dentofacial injuries in Cameroon. The limitations of this research include the fact that use of protective gear like helmets and comparison to other causes of dentofacial injuries were not assessed.

\section{Conclusion}

Dentofacial injuries in commercial motorcycle accidents constitute serious injuries necessitating hospital admission and long treatment time with attendant cost. Preventing these injuries will serves as a form of poverty reduction as money that will be used by the victim to better their life is not used to correct deformities or treat injuries. Furthermore, this supports the need for training of maxillofacial surgeons by Cameroonian government to ensure the quality care among affected individuals.

\section{References}

1. Solagberu BA, Ofoegbu CKP, Nasir AA, Ogundipe OK, Adekanye AO, Abdur-RahmanLO. Motorcycle injuries in a developing country and the vulnerability of riders, passengers, and pedestrians. Inj Prev2006; 12:26668.

2. Adogu PO, Ilika AL, Asuzu AL. Predictors of road traffic accident, road traffic injury and death among commercial motorcyclists in an urban area of Nigeria. Niger J Med 2009; 18(4):393-7.

3. Chalya PL, Mabula JB, Ngayomela IH, Kanumba ES, Chandika AB, Giiti G, Mawala B, Balumuka DD. Motorcycle injuries as an emerging public health problem in Mwanza City, north-western Tanzania. Tanzania J Health Res 2010; 12(4):214-21.

4. Nwadiaro HC, Ekwe KK, Akpayak IC, Shitta H. Motorcycle injuries in North-Central Nigeria. Niger J Clin Pract 2011; 14(2):186-9. 
5. Hashim H, Iqbal S. Motorcycle accident is the main cause of maxillofacial injuries in the Penang Mainland, Malaysia. Dent Traumatol 2011; 27(1):19-22.

6. Breitenbach TC, Pechansky F, Benzano D, Boni RD. High rates of injured motorcycle drivers in emergency rooms and the association with substance use in Porto Alegre, Brazil. Emerg Med J 2012; 29(3):205-07.

7. Alicioğlu B, Yalniz E, Eskin D, Yilmaz B. Injuries associated with motorcycle accidents. Acta Orthop Traumatol Turc. 2008; 42(2):106-11.

8. Ramli R, Abdul Rahman R, Abdul Rahman N, Abdul Karim F, Krsna Rajandram R, Mohamad MS, Mat Nor G, Sohadi RU. Pattern of maxillofacial injuries in motorcyclists in Malaysia. J Craniofac Surg 2008; 19(2):31621.

9. Oginni FO, Ugboko VI, Ogundipe O, Adegbehingbe BO. Motorcycle-related maxillofacial injuries among Nigerian intracity road users. J Oral Maxillofac Surg 2006; 64(1):56-62.

10. Bassey GO, Anyanechi CE, Chukwuneke FN. Maxillofacial injuries in Calabar south south, Nigeria: a 5 year study of jawbone fractures. Niger J Med 2011; 20(2):245-49.

11. Chrcanovic BR, Freire-Maia B, Souza LN, Araújo VO, Abreu MH. Facial fractures: a 1- year retrospective study in a hospital in Belo Horizonte. Braz Oral Res 2004; 18(4):322-28.

12. International Association of Public Transport. Report on statistical indicators of public transport performance in Africa. Version 1.3 - Final version. Trans
Africa April 2010:20

13. Lee MC, Chiu W'T, Chang LT, Liu SC, Lin SH. Craniofacial injuries in unhelmeted riders of motorbikes. Injury 1995; 26(7):467-70.

14. Chalya PL, Mabula JB, Dass RM, Mbelenge N, Ngayomela IH, Chandika AB, Gilyoma JM. Injury characteristics and outcome of road traffic crash victims at Bugando Medical Centre in Northwestern Tanzania. J Trauma Manag Outcomes 2012; 6(1):1-8

15. Adeyemo WL, Ladeinde AL, Ogunlewe MO, James O. Trends and characteristics of oral and maxillofacial injuries in Nigeria: a review of the literature. Head Face Med 2005; 1:7-15.

16. Adebayo ET, Ajike OS, Adekeye EO. Analysis of the pattern of maxillofacial fractures in Kaduna, Nigeria. Br J Oral Maxillofac Surg 2003; 41(6):396-400.

17. Ogunlewe MO, James O, Ladeinde AL, Adeyemo WL. Pattern of paediatric maxillofacial fractures in Lagos, Nigeria. Int J Paediatr Dent 2006; 16(5):358-62.

18. Júnior SM, Santos SE, Kluppel LE, Asprino L, Moreira RW, de Moraes M. A comparison of motorcycle and bicycle accidents in oral and maxillofacial trauma. J Oral Maxillofac Surg 2012; 70(3):577-83.

19. Hussaini HM, Rahman NA, Rahman RA, Nor GM, Ai Idrus SM, Ramli R. Maxillofacial trauma with emphasis on soft-tissue injuries in Malaysia. Int J Oral Maxillofac Surg.2007; 36(9):797-801.

20. Ehikhamenor E, Agwubike EO. The need for blood alcohol concentration (BAC) legislation in Nigeria. Trop J Pharm Res 2004; 3 (1): 319-27 